DOI: $10.30519 /$ ahtr.668220

Advances in Hospitality and Tourism Research (AHTR)

\title{
REVIEW OF MENU MANAGEMENT PROCESS MODEL WITH A CASE STUDY
}

\author{
Oğuz NEBİOĞLU 1 \\ Department of Tourism Guidance, Alanya Alaaddin Keykubat University, Turkey \\ ORCID: 0000-0002-3436-7754
}

\begin{abstract}
This study examines how the Menu Management Process Model is realized in practice. To the best of the author's knowledge, this study is the first to evaluate this model empirically by applying the case study method to a boutique café. Data were obtained from observations, document analysis, and interviews. The findings revealed which topics attracted attention during the process, the revisions made to the menu cards, and the reasons for these revisions. More drastic changes were made to the food menu than the beverage menu. Food menu revisions included making changes (17 items) and eliminating items (9 items) whereas beverage menu revisions were making only changes (17 items). While 15 new products were added to the food menu, no new products were added to the beverage menu. The process followed the cyclical path theorized in the model. Finally, suggestions were made for researchers and practitioners.
\end{abstract}

\section{Article History}

Received 31 December 2019

Revised 08 June 2020

Accepted 10 June 2020

Keywords

Menu management process

Case study

Food and beverage management

\section{INTRODUCTION}

In its simplest terms, a menu is a list of dishes and/or beverages offered in a food and beverage business. More extensively, it represents a plan by which food service operations organize food and beverage supply products and services (Kivela, 2003). In parallel with the increasing importance of the dining experience and other developments in the food and beverage sector,

\footnotetext{
${ }^{1}$ Address correspondence to Oğuz NEBİOĞLU (PhD), Department of Tourism Guidance, Alanya Alaaddin Keykubat University, Alanya, Antalya, TURKEY. E-mail: oguz.nebioglu@alanya.edu.tr
} 
the menu has gained additional functions to listing items. For business managers, a menu is a mean of communication between the restaurant and guests (Bowen \& Morris, 1995) and lies at the heart of the restaurant's marketing activities (McCall \& Lynn, 2008). It is also a critical element in forming the guests' first impressions of the restaurant (Antun \& Gustafson, 2005). A well-planned menu provides effective cost control, raises consumer demand, and increases profit (Özdemir, 2012). Given these functions, the menu is regarded as an area that food and beverage businesses should prioritize to ensure the success of the restaurant (Bernstein et al., 2008). Because they have such different meanings for food and beverage businesses, menus need to be properly managed to be an effective communication tool, increase demand, provide effective cost control, and raise profits. Several studies have investigated these effects of menus, focusing on consumers, chefs, and restaurant managers, analyzing the menu-related data of food and beverage establishments, and evaluating menus conceptually.

Studies of consumers mostly examine menus within the framework of consumer opinions to evaluate their effectiveness as marketing tools (Dipietro et al., 2006; Hwang \& Lorenzen, 2008; McCall \& Lynn, 2008; Guéguen et al., 2012; Hou et al., 2017). Studies of chefs and restaurant managers mostly focus on the process of choosing products to include on the menu (Seyitoğlu, 2017; Aktaş Alan \& Suna, 2019) or product development (Ottenbacher \& Harrington, 2007, 2009). Studies of business data (costs, sales figures, contribution margins etc.) aim to measure menu performance (LeBruto et al., 1995; Morrison, 1996; Kwong, 2005; İyitoğlu \& Nebioğlu, 2017). Conceptual studies aim to develop a holistic understanding of topics like menu analysis (Taylor \& Brown, 2007) menu performance (Özdemir, 2012), and administrative aspects (Çalışkan \& Özdemir, 2011; Özdemir \& Çalışkan, 2014).

Menu management includes a series of steps that require various processes, such as comprehensive market research, product selection, pricing of menu items, and the creation of menu cards, with a consecutive dynamic structure (Antun \& Gustafson, 2005; Choi et al., 2010). Empirical studies generally focus on specific steps whereas conceptual studies provide more holistic information about the overall process. However, the conceptual studies lack empirical data to support the process. The present study was designed to overcome the shortcomings of both empirical and conceptual studies. It approaches the issue from a wider perspective, from planning to performance measurement, while supporting this holistic approach with empirical findings. More specifically, it uses a case study to 
evaluate Çalışkan and Özdemir's (2011) “Menu Management Process Model".

\section{LITERATURE REVIEW}

\section{Studies on Menu Management}

There are many studies on menu management in the literature (Özdemir \& Nebioğlu, 2018), which examine menus in terms of various dimensions, such as planning, pricing, design, and analysis (Özdemir \& Çalışkan, 2014). Menu planning is the first menu management research area. Such studies aim to determine how food and beverage establishments construct their menus. Kivela (2003), for example, used the menu planning qualitative variables model to identify three topics in the planning stage, namely gastronomic, financial, and marketing variables. The study developed a formal model that practitioners can use in menu planning. Glanz et al. (2007) examined the issues affecting menu planning in chain restaurants. The findings revealed that the main criterion in planning is profit, although health and nutrition are also important. Johnson et al. (2002) also reported that health-related issues are an important criterion in planning for chefs. Finally, Seyitoğlu (2017) identified five prominent topics in menu planning: predecessors, key issues, influential actors and their roles, trial and error, and problems-difficulties. The study also concluded that consumer demand is an important criterion in menu planning.

Menu planning also encompasses developing new products. Ottenbacher and Harrington (2007) showed that new product development in Michelin Star restaurants passes through seven stages. In contrast, for fast food restaurants, they identified 13 stages (Ottenbacher \& Harrington, 2009). They concluded that this difference occurred because, as businesses, fast food restaurants work at larger scales and with greater risks. Sezgin et al. (2008) showed that hotels are not so open to innovation in menu planning. Cho et al. (2018) revealed that supplier diversity and partnership power were important factors that encouraged new product development. Menu planning is related to menu variety as well. Bernstein et al. (2008) showed that customers prefer menus that change daily over fixed menus, while Baiomy et al. (2019) found that menu diversity increases customer satisfaction.

The second area is menu pricing, particularly regarding psychological pricing. For example, Parsa and Naipaul (2008) compared 
menu pricing in fine dining and fast food restaurants. They found that fine dining restaurants used ' 00 ' after the comma in prices to emphasize quality whereas fast food restaurants used ' 99 ' to highlight price. Hançer et al. (2007) reported similar results regarding the use of '00' to suggest high quality. Raab et al. (2009) tested a model called PSM (Price Sensitivity Model) to explain consumers' price sensitivity on guests in a restaurant in Hong Kong. Findings showed that price can be determined according to customer sentiment. Yim et al. (2014) proposed the hedonic pricing model to show how food quality and atmosphere are important factors in determining menu item prices.

The third important dimension to menu management is design. Studies in this area often examine how menu cards are designed and their impact on consumers and businesses. Magnini and Kim (2016), for instance, examined the effects of font size, background color, and menu weight on consumer perceptions, reporting that italic fonts and heavy menus create perceptions of quality service, whereas background color had no effect. Kim and Lee (2020) also measured the effect of menu card background color on consumers' psychological processes (the dynamics of emotional arousal, temptation, and self-control). They found that a red background causes greater emotional arousal and temptation than blue or white. Focusing on images, Hou et al. (2017) found that customers are more likely to select menu items that are pictured in the menu and are willing to pay more money for those items. Finally, Baiomy et al. (2019) concluded that good menu design generally increases customer satisfaction.

Another area covered by the menu design is menu layout. Research shows that the positioning of menu items in certain places on the menu card can increase sales. Thus, menu designers must place the products that the restaurant wants to sell the most in these positions (Reynolds et al. 2005; Choi et al., 2010; Kim \& Magnini, 2016). However, other studies have contradicted these findings. Both Bowen and Morris (1995) and Kincaid and Corsun (2003), for example, found that the positioning of menu items did not significantly change sales.

Menu labels are another area of menu design. Research suggests that menu items with evocative labels may positively affect consumer behavior. Dipietro et al. (2006) found that consumers prefer menu items labeled as 'healthy'. Hou et al. (2017) also showed that descriptive menu names make consumers more positive about the item, more willing to pay, and more likely to purchase it. Özdemir and Nebioğlu (2018) reported that such descriptive names are frequently used in menu cards. For example, $41.6 \%$ 
of the restaurants they examined named some dishes in their menus as 'home cooked', 'mother's style', or 'delicious'.

Menu design also includes descriptions of the items, which can positively affect consumer attitudes, perceptions, and behavioral intentions. For example, McCall and Lynn (2008) reported that menu items with detailed descriptions increase the perception of quality, purchase intent, and expected price. Hwang and Lorenzen (2008) showed that nutritional information and declarations of healthiness make customers more positive about the items. Kim and Lee (2020) also demonstrated the importance of health-related information. Specifically, presenting calorie information about food items reduced customers' indulgent food preferences while Baiomy et al. (2019) showed that explanations about menu items increased customer satisfaction. Finally, adding various symbols next to menu items may affect consumer food choices (Guéguen et al., 2012).

Menu analysis, which is the fourth area, measures menu performance (Özdemir \& Nebioğlu, 2015). It has become prominent since the 1980s. Research initially tried to determine the performance of menu items according to certain criteria. These included volume and food cost percentage (Miller, 1980), volume and contribution margin (Kasavana \& Smith, 1982), and weighted contribution margin and food cost percentage (Pavesic, 1983). Later, other criteria were added to these matrix-based models. For example, LeBruto et al. (1995) added labor costs to Kasavana and Smith's model while Cohen et al. (1998) added food cost, price, labor cost, popularity, and contribution margin. Additionally, other models of menu performance were introduced, such as data envelopment analysis (Reynolds, 2004) and activity-based costing (Raab \& Mayer, 2007).

In contrast, Jones and Mifli (2001) investigated menu analysis approaches in restaurant chains in the UK from the practitioners' perspective. They found that businesses applied three different strategies: minimal adjustment, menu development, and menu item development. According to Özdemir and Nebioğlu (2015), menu performance models are mostly adapted from other fields, such as accounting, finance, strategic management, and performance management. Focusing on practitioners, they found that chefs evaluated their menus in terms of plate waste analysis and customer feedback.

Thus, different studies address specific dimensions of menu management, while only a few studies have examined several dimensions together. Morrison (1996), for example, investigated menu planning and 
menu analysis in upscale restaurants, revealing that the availability and personnel competencies with the products were important factors; however, restaurant practitioners did not apply formal menu analysis. Similarly, Aktaş Alan and Suna (2019) found that product features and customer requests influence menu planning while customer satisfaction affects menu analysis. Neither study addressed pricing, design, or operations. On the other hand, Antun and Gustafson (2005) focused on restaurant and club menu pricing, design, and implementation but not planning or analysis. To fill this gap, the present study uses a very comprehensive model that includes all the steps discussed above.

\section{Menu Management Process Model}

The Menu Management Process Model (Özdemir \& Çalışkan, 2014) is a holistic conceptual model that covers menu creation, implementation, and evaluation in a specific order and in a comprehensive manner. According to the model, menu management forms a continuous cycle of five stages (planning, pricing, design, operation, analysis). The planning phase examines how the menu is created. The pricing phase deals with how to determine the prices of menu items. The design phase includes the formation of the menu card. The operation phase defines the use of the menu in the business. The analysis phase involves measuring the performance of menu items.

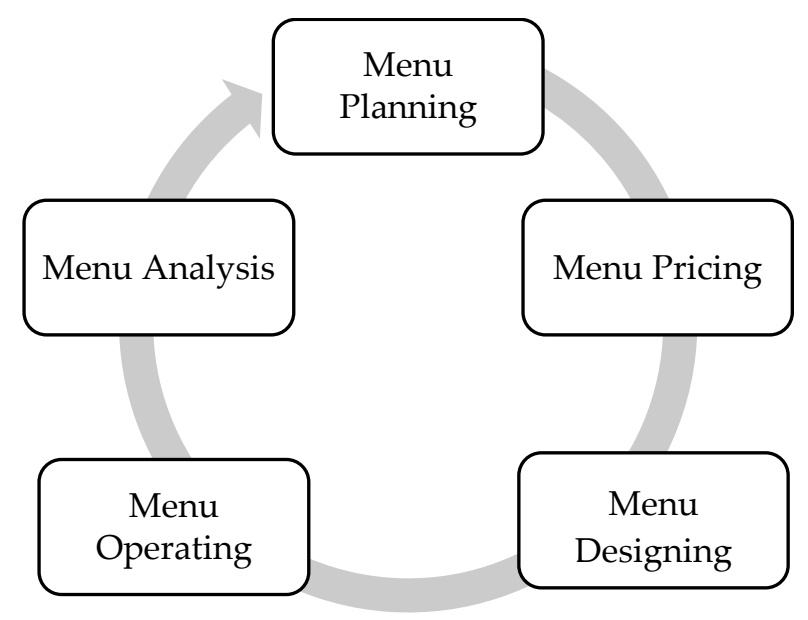

Figure 1. Menu Management Process Model

As seen in Figure 1, the cycle starts with menu planning and continues until the menu analysis and revisions to the menu are determined 
after the analysis. The desired changes are made to planning, pricing, and design respectively before the menu is put back into practice. Thus, it is a cyclical model in which the menu is constantly developed (Çalışkan \& Özdemir, 2011).

Compared to research that examines the menu itself, the Menu Management Process Model approaches the topic of menu management more comprehensively and holistically. Most of the studies reviewed earlier examined single dimensions, such as planning, pricing, design, or analysis, whereas the Menu Management Process Model considers all of them in a specific order (planning, pricing, design, implementation, and analysis) within a connected model. It thus covers all the administrative studies of menus.

However, while most studies are empirical, the present study's model is only conceptual. That is, although it provides valuable conceptual information, it is not known exactly how this model performs in practice. Accordingly, the present study aims to understand how the menu management dimensions, presented independently in the literature, work in the new model. To the best of the author's knowledge, this is the first empirical test of the Menu Management Process Model. In addition, most empirical studies of menus are made from the consumer's perspective rather than the business perspective (Özdemir \& Nebioğlu, 2018). Therefore, the present study can contribute to the literature by examining the model from the perspective of operators.

Three research questions were identified regarding the issues that arise in a food and beverage business in relation to the different stages of the model.

- What are the main issues during the menu management process (planning, pricing, design, operating, and analysis) implemented in a food and beverage business?

- After the analysis phase, what revisions have been made in the food and beverage menu?

- What are the reasons for these revisions?

By answering the above questions, the study provides an opportunity to holistically examine the stages (planning, pricing, design, operating, and analysis) which were discussed as independent dimensions of menu design in the related literature. This study also shows how the conceptual model may be realized in practice, particularly whether menu management is a cyclical process or not. Academicians can gain in-depth 
knowledge about the stages presented in the conceptual model and how each one of them is applied in the field. For practitioners, the model can guide future initiatives in menu management.

\section{METHODOLOGY}

In order to answer the above research questions, a qualitative case study method was selected. A case study is an approach in which the researcher collects information about real life, a situation, or multiple situations through various sources of information, and identifies status determination, description, or situation themes (Creswell, 2013). The subject is examined with a variety of lenses rather than just one in order to allow multiple subjects to be exposed and understood (Baxter \& Jack, 2008). This makes the case study an appropriate research method to understand the dimensions of menu management in depth. Since the research focused on only one food and beverage business, a single instrumental case study was chosen. Case studies are a prevalent research method for academic studies on menu management, examining the effects of different aspects of a menu (LeBruto et al., 1995; Cohen et al., 2007) like menu pricing (Kelly et al., 1994), menu design (Bowen \& Morris, 1995), or menu variety (Bernstein et al., 2008). The present study also identified a single food and beverage business as a research area in order to consider all stages of the Menu Management Process Model in detail without confusion.

\section{Study Setting}

A food and beverage company that was planning a new opening in Alanya in southern Turkey was chosen as the research area. The facility became operational in early 2016 as a boutique café. It is an independent food and beverage business that does not work within a chain or under a franchising agreement; hence its menu is not managed from any center. A new business was selected for the case study in order to easily examine all the stages of the Menu Management Process Model. Business owners and the food and beverage business consultant were interviewed and informed about the Menu Management Process Model. An agreement was reached to monitor the stages of the Menu Management Process Model after the café opened. The fact that the researcher knew both the operators and the consultant made the implementation of this model more convincing. The researcher 
did not intervene in the process except for suggesting that the stages be implemented in the order specified in the model.

\section{Data Collection Process and Tools}

Data collection took 18 months. Creating the first menu cards after the planning, pricing, and design stages took about six months, while the operation and analysis stages from when the business became operational took 12 months. This period was long enough to observe all the steps of the Menu Management Process. Three different data collection tools were used: observations, document analysis, and interviews. After gaining permission from the operators and the consultant, the researcher took part as an observer in all the business-planning meetings (17 meetings). The essential parts of the meetings were noted without using a formal observation tool. Document review covered sales documents (15 pages), the first menu cards in the opening phase (18 pages) and revised menu cards ( 2 pages) after menu analysis, photos of food and beverages in the menus (77 photos), standard recipes (22 pages), and tables to calculate item costs (3 pages).

Interviews were conducted with the operators and consultants to understand how the process proceeded. A two-part, semi-structured interview form was developed based on information in the literature to obtain in-depth information from the participants. The first part had eighteen open-ended questions in six categories regarding the stages of the model. The first five questions considered the basic stages of the management process while the last question asked about changes that took place after the process. The second part covered the demographic characteristics of the participants, such as gender, age, and educational background. Expert opinions were obtained to evaluate the form before it was finalized in accordance with the necessary regulations.

One-to-one interviews were conducted with the three participants: two operators and one consultant. The interviews, which were recorded with a camera and voice recorder, lasted 144 minutes 28 seconds in total (average interview time 48 minutes). The recordings were then transcribed (33 pages, 13,958 words). The first participant was both a partner of the café and a chef. The second participant, the other operator, dealt with administrative and financial affairs. The last participant was a professional consultant advising on the opening of the café. No participants were available to provide detailed information about the process. That is, this study included all the participants who affected the process. 


\section{Data Analysis}

The collected data were subjected to content analysis. Such analysis can be done either inductively or deductively (Elo \& Kyngäs, 2008). The deductive approach was preferred here because the main dimensions of the model are known. The data (documents, observation notes, and interview recordings) were examined by two researchers experienced in qualitative research, and coded in accordance with the five main themes of the Menu Management Process Model with the help of a qualitative data analysis program. In this way, sub-categories were created. Cohen's Kappa analysis was then conducted to determine the coding reliability. The similarity ratio of the two coders was calculated as $73.3 \%$, which indicates a good level of agreement between coders (Kılıç, 2015). Finally, the sub-categories were identified and named after a focus group meeting that included three academicians from the gastronomy and culinary arts department and one academician from the business department.

\section{Trustworthiness}

Four main issues increase trustworthiness in qualitative research: credibility, dependability, confirmability, and transferability (Başkale, 2016). Credibility refers to the relevance of the analysis to the focus of the research (Graneheim \& Lundman, 2004). To increase the credibility of the present study, the research area was chosen to ensure that all stages of the model could be observed. In addition, specific techniques like prolonged involvement (taking part in all meetings, accessing all documents) and participant confirmation (member checking and peer debriefing) were used. The researcher collected the data over a long period (18 months) by attending all relevant meetings and using different data sources. The findings were discussed with both the participants and academic experts. To increase dependability, diverse data sources were used, more than one researcher carried out the analyses, and the model was examined in the finest detail. To maximize confirmability, all data (camera and sound recordings, documents, photographs, observation notes) were recorded and stored. Direct quotations by the participants were included in the findings regarding the process and the reasons for revising the menus. In addition, the menu cards before and after revisions are presented. Transferability refers to the extent to which findings can be transferred to other settings or groups. Although the results of qualitative research are not intended to be generalizable, the elements that ensure transferability should be included. In this study, as much information as possible was given 
(research area, method, analysis, and findings) so that readers can get the clearest understanding of the process as possible.

\section{FINDINGS}

After the analysis, 19 sub-categories were gathered under five main themes related to the first research question. The findings are given in the order presented in the model.

\section{Menu Planning}

The first concept to be considered in menu planning is the business concept. The participants stated that they started out with a good coffee and good cheesecake motto, and designed the business based on a book café concept. This was influenced by the location on the top floor of a seven-story bookstore. The operators chose the concept of the café as a place where book lovers can have a pleasant time before or after shopping. Thus, the target audience was upper-middle-class consumers who like to read books complemented by good food and beverages.

In accordance with this concept and the target audience, the operators and the consultant aimed to offer home-made, natural products. At this stage, they developed three basic food and beverage-related criteria for the menu items: first, preparing the majority of products on site; second, achieving a balance between sweet and savory in the food menu, and between hot and cold in the beverage menu; third, including both local and international delicacies.

Accordingly, they decided that most products would be prepared in the company's kitchen, although preparation of traditional foods that required specialist skills (such as kıvrım desserts or spinach pastries) could be outsourced. Similarly, outside suppliers would provide beverages like colas, fruit juices, and cold teas, whereas all other drinks would be prepared on site. Regarding the balance of cuisines, they decided to include 22 products on the food menu and 29 products on the beverage menu.

The aim was that all products on the menu should be prepared and sold daily rather than stored. Only 3 food items were prepared by suppliers and all foods would be prepared using classical techniques and ingredients, without any industrial pastry additives. This also emphasized the 
naturalness of the food. All the teas, coffees, and homemade cold beverages were prepared on site (20 products) whereas carbonated beverages (9 products) were bought from suppliers, as in other food and beverage businesses.

Planning for the food menu did not consider the sweet-savory balance as 17 products were sweet and only five products were savory because it was predicted that these sweet products would be preferred in food and beverage matches. Seventeen drinks were hot beverages and 12 were cold. For the food menu, 11 products represented local cuisine (e.g. Sshaped cookies, sadrazam delight, homemade baklava, and kivrım dessert) while 11 were international (e.g. cheesecake, magnolia pudding, and cherry-almond cake). Sixteen drinks were local (e.g. nerdek (cranberry syrup), Alanya's local almond coffee, Turkish coffee, and Alanya-style lemonade) while 13 were widely-known international beverages (e.g. cola, cold tea, espresso, and cappuccino). Indeed, the café was named 'Nerdek' after the local drink. In addition, strategies were decided for presenting food and beverages together with names, such as 'nice couples' and 'teatime', which were expected to make the menu distinctive.

Suppliers were also considered while choosing products. For example, only certain brands would be used for the dessert ingredients, such as dairy products, sugar, and flour. These materials are bought from a supermarket that the operators made an agreement with. Regarding fresh ingredients, such as fruit, herbs and herbal teas, should be supplied from local producers in the neighborhood market. Finally, some businesses grew cranberry fruits (for nerdek) in their own gardens. Thus, the business identified three different supply sources for the ingredients of the menu items: supermarkets, the neighborhood street market and the garden.

The next consideration in planning the menu was personnel qualifications. The operators realized it was essential to employ personnel capable of producing the planned menu items, especially preparing homemade and natural products while avoiding industrial pastry-making techniques. It was envisaged that university students studying in this field would be employed part-time for preparing and serving food and beverages.

Thus, the planning resulted in a food and beverage menu offering both local and international cuisine, sweet and savory foods, as well as hot and cold beverages. The menu was also based mostly on products that the business itself produced and partially by outsourcing. The menu placed the foods in 11 categories and the beverages in 4 categories. These findings revealed the 
following decisive factors in menu planning for this case: the business concept, target audience, characteristics of menu items and recipe development, material resources and suppliers, and personnel qualifications and employment.

\section{Menu Pricing}

The second stage of the menu management process concerned calculating costs, which the operators did using objective methods. They first estimated the material costs based on the recipes. Personnel and other costs were then added to determine each menu item's total cost. Next, the operators decided on an average profit ratio of $30 \%$ for each menu item. However, the interviews revealed that there was also a subjective element to the pricing methods. That is, the participants compared similar products in the market to derive a reference price. In addition, they monitored competitors' prices and the reactions of customers as part of a reasonable pricing method. Prices were listed as ' 00 ' and ' 50 ' after the comma in order to create a perception of quality. Thus, the pricing phase began by calculating the material and other costs of making each food and beverage item. Finally, profit, competitors, consumer reactions, and business image were considered to derive the final menu prices.

\section{Menu Design}

Menu design is the stage when the menu card is created. The findings for this stage fell into four sub-categories. First, the operators decided on the physical characteristics of the menu card: a wooden board with menu items written on both sides. Both the food and beverage menu were in shades of red to reflect the color of nerdek. In addition, items were listed in both Turkish and English to cater for local people and foreign visitors. However, the operators rejected using more than two languages to avoid confusion in the menu. They also decided not to include pictures of the items due to the concern that differences between the pictures and the actual products might reduce customer satisfaction and because the menu card was too small to include pictures of every item.

Other physical properties of the menu card were the different font colors and sizes. Three different font colors were used to distinguish the menu categories, Turkish menu items, and English menu items. Four different font sizes were used, including menu item descriptions. One of the 
most striking issues in the design was naming of menu items. Most items (e.g. cheesecake with lemon or Turkish coffee) were given standard names as in many food and beverage businesses. A few items, however, were given more stimulating labels, such as "Alanya-style lemonade" and "Homemade baklava". The operators decided to include descriptions for a few items. For example, the 'tea-time' item explained how many customers it was for and its content, while the granola items explained that they could be served with milk or yoghurt.

In designing the menu, the operators also paid attention to strategically positioning certain menu items. For example, products that were expected to sell well were placed at the top, while other products were framed to attract attention and increase sales, specifically 'nice couples' and 'tea time' in the food menu and fresh orange juice, nerdek and Alanya-style lemonade in the beverage menu. Figure 1 shows the menu cards as they appeared after the menu design phase. The 22 products selected in the planning stage had been transformed into a structure of 28 menu items, grouped in 11 categories, including combinations of food and beverages, such as nice couples, tea-time and mixed cookie plates. The beverage menu included all the previously chosen 29 beverage items, grouped in 4 categories.

During the first three stages of the menu management process, the operators searched for and recruited one full-time staff working in the kitchen and eight part-time staff working in the service in accordance with the concept and menu. After introducing the menu to the staff, the operators informed them about the working system of the business before the operation phase, which began in January 2016. 


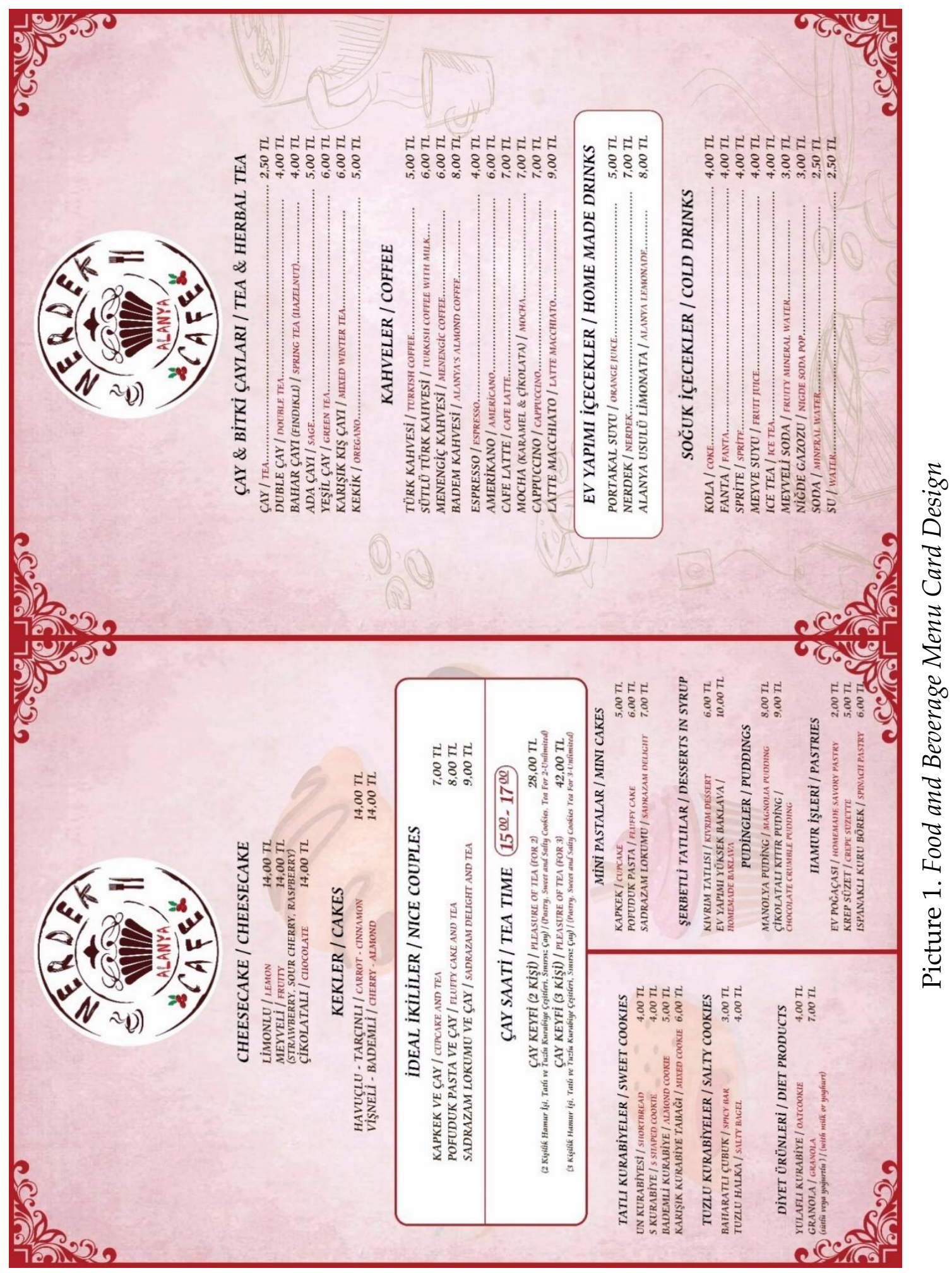




\section{Menu Operating}

This phase refers to the stage when the food and beverage business begins to serve customers. The first operational issue is the opening hours. Since the business operated as part of the bookstore, its working hours were also 07:30-21:30. The employees were given single shifts in the kitchen and double shifts in service, taking into account the work load density of the café. As a new business, it was important to focus on promotional activities, so local media (press journalists and television broadcasters) were invited to learn about the business. In addition, the business developed itself on social media as well by creating a profile on platforms like Facebook, Instagram and Foursquare. Finally, the operators paid attention to word-ofmouth marketing, emphasizing the importance of guests' comments about the cafe and sharing on social media.

A personnel training regarding presentation and operation was conducted both before and after opening. Service staff was trained in how to serve each food and beverage item while kitchen staff were told to prepare items in a standard form. Customer feedback was another key topic mentioned in the operation phase. This was received in three different ways. The first was from customer questionnaires. The second was face-toface. Here, the operators talked to customers to get their ideas about the operation of the business and their satisfaction with the food and beverages offered. The third source was social media reviews, as ratings and comments on these platforms make a significant contribution to the operation. In short, the operations phase focused on determining the opening hours, marketing and promotion applications, in-service training and customer relationship management. The last step of the menu management process was analysis.

\section{Menu Analysis}

The operation and menu analysis took place simultaneously between January 2016 and January 2017. Menu analysis determines to what extent the actual menu meets customer and business needs. Two different menu analysis methods are generally applied. The first is plate waste analysis, which involves monitoring what is left on the plates returned from the guests to determine which products are not consumed. Secondly, the business used a food and beverage automation program to record the sales of each food and beverage product. Measuring the popularity and profits of each product, they made decisions about revising the menu. 
These findings from the 18-month data collection phase showed what strategies this food and beverage business implemented based on stages of the menu management process model. As Çalışkan and Özdemir (2011) note, the model is cyclical so the final stage of analysis serves as a catalyst for identifying the unsatisfactory or missing elements in the menu and ensures continuity of the management process.

Table 1 shows the main topics in the Menu Management Process in relation to the first research question. In menu planning, the key topics are the business concept, target audience, features of menu items and determination of recipes, material resources and suppliers, and personnel selection. Both objective and subjective pricing methods are used in determining the cost of food in the pricing process while the operating concept plays a decisive role in the price ending strategy. In menu design, the physical characteristics of the menu card, naming, descriptions, and strategic positioning of menu items are notable. In the operation phase, opening hours, promotional activities, personnel training, and customer relations are the most prominent topics. Finally, menu analysis focuses on plate waste analysis and measuring demand for products through the food and beverage automation program. This stage identifies those points that do not match with the aims of the business.

Table 1. Key Findings from the Menu Management Process

\begin{tabular}{|c|c|c|}
\hline $\begin{array}{l}\text { Menu } \\
\text { Management } \\
\text { Process } \\
\text { Model } \\
\text { Stages }\end{array}$ & $\begin{array}{l}\text { Sub- } \\
\text { Categories }\end{array}$ & Sample Quotes \\
\hline \multirow{4}{*}{$\begin{array}{l}\text { Menu } \\
\text { Planning }\end{array}$} & $\begin{array}{l}\text { Business } \\
\text { Concept }\end{array}$ & $\begin{array}{l}\text { "We thought of designing this place as a book cafe concept." P1 } \\
\text { "We thought of this place, not as an ordinary neighborhood coffee, but } \\
\text { a little more as a concept, a different style of boutique cafe that appeals } \\
\text { to taste." P2 }\end{array}$ \\
\hline & $\begin{array}{l}\text { Target } \\
\text { Audience }\end{array}$ & $\begin{array}{l}\text { "We can say that we targeted the audience, which we call the middle- } \\
\text { upper segment with a higher income level, both in terms of } \\
\text { presentation and product variety." P2 }\end{array}$ \\
\hline & $\begin{array}{l}\text { Features of } \\
\text { Menu Items }\end{array}$ & $\begin{array}{l}\text { "Natural and homemade products ... the purpose of the cafe was that." } \\
\text { P3 } \\
\text { "We thought the products would be special. We do not use frozen } \\
\text { products." P1 }\end{array}$ \\
\hline & $\begin{array}{l}\text { Food } \\
\text { Resources and } \\
\text { Suppliers }\end{array}$ & $\begin{array}{l}\text { "We especially use certain brands ... We also bring coffee from Italy ... } \\
\text { Our fruit and vegetables come from the local bazaar; we provide } \\
\text { products such as herbal teas from local suppliers ... We also produce } \\
\text { cranberry plants in our own orchard for the beverage (nerdek) that } \\
\text { gave the cafe its name." P1 }\end{array}$ \\
\hline
\end{tabular}




\begin{tabular}{|c|c|c|}
\hline & $\begin{array}{l}\text { Personnel } \\
\text { Selection }\end{array}$ & $\begin{array}{l}\text { "Since we aimed to use natural products in the kitchen, we selected the } \\
\text { employees from people who did not deal with industrial pastry." P1 }\end{array}$ \\
\hline \multirow{4}{*}{$\begin{array}{l}\text { Menu } \\
\text { Pricing }\end{array}$} & $\begin{array}{l}\text { Determina- } \\
\text { tion of Food } \\
\text { Costs }\end{array}$ & $\begin{array}{l}\text { "Cost was calculated first. We made the cost calculation of the } \\
\text { products we made and then priced." P1 }\end{array}$ \\
\hline & $\begin{array}{l}\text { Objective } \\
\text { Pricing }\end{array}$ & $\begin{array}{l}\text { "Minimum raw material expense between } 25-40 \% \text {; the average } \\
\text { monthly expense (electricity, water, internet, rent, and personnel } \\
\text { expense) of this place corresponds to } 30 \% \text { In other words, the rate of } \\
\text { profit of the cafe is approximately } 30 \% . " \mathrm{P} 2\end{array}$ \\
\hline & $\begin{array}{l}\text { Subjective } \\
\text { Pricing }\end{array}$ & $\begin{array}{l}\text { "We made a price comparison in the market and evaluated accordingly } \\
\text { and determined the prices in that way. In such cafes, it was generally } \\
\text { the same: the price of tea was } 2.5 \mathrm{TL} \text {, and we made it } 2.5 \mathrm{TL} . " \text { P1 }\end{array}$ \\
\hline & $\begin{array}{l}\text { Price Ending } \\
\text { Strategies }\end{array}$ & $\begin{array}{l}\text { "Quality had to be emphasized here. We thought that numbers like } 9 \\
\text { after the comma would not be suitable for our concept." P3 }\end{array}$ \\
\hline \multirow{4}{*}{$\begin{array}{l}\text { Menu } \\
\text { Designing }\end{array}$} & $\begin{array}{l}\text { Physical } \\
\text { Characteris- } \\
\text { tics of the } \\
\text { Menu Card }\end{array}$ & $\begin{array}{l}\text { "We made our menu by pasting it on a standard double-sided wooden } \\
\text { board." P2 } \\
\text { "The color was very pale, pinkish ... in the shades of our signature } \\
\text { beverage (Nerdek)" P3 } \\
\text { "English is a universal language. Since Germans and Russians speak } \\
\text { English, there is no problem. There is a lot of language confusion; we } \\
\text { are for simplicity. An English menu is enough." P2 } \\
\text { "We didn't thought of using food and drink photos from the } \\
\text { beginning" P3 }\end{array}$ \\
\hline & $\begin{array}{l}\text { Naming Menu } \\
\text { Items }\end{array}$ & $\begin{array}{l}\text { "In addition to using standard names in the menu, we gave some } \\
\text { products some unusual names. Such as Alanya style lemonade and } \\
\text { homemade baklava." P3 }\end{array}$ \\
\hline & $\begin{array}{l}\text { Descriptions } \\
\text { of Menu Items }\end{array}$ & $\begin{array}{l}\text { "We have added various explanations about how many people will be } \\
\text { offered some products or how to serve them." P1 }\end{array}$ \\
\hline & $\begin{array}{l}\text { Strategic } \\
\text { Location of } \\
\text { Menu Item }\end{array}$ & $\begin{array}{l}\text { "Drinks such as tea and coffee are highly preferred. People often focus } \\
\text { their attention on the top of the menu card. That's why we put tea } \\
\text { varieties on top." P2 } \\
\text { "We thought that the products we wanted to be sold should be more } \\
\text { visible and we made a placement on the menu card accordingly." P3 }\end{array}$ \\
\hline \multirow{4}{*}{$\begin{array}{l}\text { Menu } \\
\text { Operating }\end{array}$} & $\begin{array}{l}\text { Business } \\
\text { Hours }\end{array}$ & $\begin{array}{l}\text { "The opening and closing hours of this place are the same as the } \\
\text { workplace (bookstore). It opens at } 07: 30 \text { and closes at } 21: 30 . " \text { P1 } \\
\text { "The waiters work here in double shifts. We do not have overtime } \\
\text { problems as the pastry master makes certain products. For example, } \\
\text { she comes at eight o'clock in the morning and leaves like five or six in } \\
\text { the evening." P2 }\end{array}$ \\
\hline & $\begin{array}{l}\text { Promotional } \\
\text { Activities }\end{array}$ & $\begin{array}{l}\text { "we gave an invitation to the local press before." P1 } \\
\text { "We promoted on Facebook and Instagram. Of course, the effect of } \\
\text { social media today is much more than advertising tools. Now we are } \\
\text { on Zomato, Foursquare." P1 }\end{array}$ \\
\hline & $\begin{array}{l}\text { Personnel } \\
\text { Training }\end{array}$ & $\begin{array}{l}\text { "We created a standard form of presentation of each dish and we did } \\
\text { a photographic study of it. Employees were informed about this, } \\
\text { especially when new employees were recruited. For example, we } \\
\text { showed how to prepare a plate. Similar training was held for the } \\
\text { presentation." P3 }\end{array}$ \\
\hline & $\begin{array}{l}\text { Customer } \\
\text { Relations } \\
\text { Management }\end{array}$ & $\begin{array}{l}\text { "We provided a survey form to our incoming customers. We evaluated } \\
\text { them" P1 } \\
\text { "Since this is a boutique cafe, I have the opportunity to talk to the } \\
\text { customers one by one, and I consider them for evaluation." P1 } \\
\text { "We definitely followed the ratings and comments on social media } \\
\text { platforms." P3 }\end{array}$ \\
\hline
\end{tabular}




\begin{tabular}{lll}
\hline & $\begin{array}{l}\text { Plate Waste } \\
\text { Analysis }\end{array}$ & $\begin{array}{l}\text { "We examined the plate waste and tried to understand the reasons for } \\
\text { this." P1 }\end{array}$ \\
\cline { 2 - 3 } Menu & $\begin{array}{l}\text { Use of Food } \\
\text { Analysis }\end{array}$ & "We are using a commercial program related to this. We learn which \\
& $\begin{array}{l}\text { Automation } \\
\text { Program }\end{array}$ & products have a higher profit rate and which products are sold and \\
& & \\
\hline
\end{tabular}

Finally, menu analysis also returns the process to a new planning phase by arranging places seen as errors or correcting deficiencies in the menu. A number of changes were made to the menu in January 2017, when the business had been operating for a year.

\section{Revisions to the Menu}

This part of the study also answers the second research question: "What revisions were made to the menu?". Various studies have classified menu changes. Jones and Mifli (2001), for example, identify five different strategies to follow after menu analysis: promotion, repositioning, retention, elimination, and making changes. Kwong (2005) suggests a similar list of strategies: keeping the menu item as it is, regulating sales prices, reducing food costs, introducing through design, personal sales, redesigning the plate, changing the position of the menu item on the menu card and removing the menu item. Since "promoting through personal sales" cannot be observed in the menu card, it differs from these strategies. Thus, five criteria for change were examined in this study: promotion, repositioning, retention, making changes and elimination. To identify these revisions more clearly, the menu items on the food menu were numbered from F1 to F28, starting at the top left while the menu items on the beverage menu card were numbered from B1 to B29.

Table 2. Revisions to the Food Menu

\begin{tabular}{llcc}
\hline $\begin{array}{l}\text { Menu } \\
\text { Revisions }\end{array}$ & Menu Items & $\begin{array}{c}\text { Frequency } \\
\text { (n) }\end{array}$ & $\begin{array}{c}\text { Percent } \\
\text { (\%) }\end{array}$ \\
\hline Promotion & - & - & - \\
\hline Repositioning & - & - & - \\
\hline Retention & F9, F10 & 2 & 7.2 \\
\hline $\begin{array}{l}\text { Making } \\
\text { changes (Price } \\
\text { Change) }\end{array}$ & F1, F2, F3, F6,F7, F8, F11, F12, F13, F14, F15, F19, F20, F21, F26 & 17 & 60.7 \\
\hline Elimination & F4, F5, F18, F22, F23, F24, F25, F27, F28 & & \\
\hline Total & & 9 & 32.1 \\
\hline
\end{tabular}


Table 2 shows the revisions to the food menu after the first year of operations. No changes were made in positioning and promotion. However, there were significant changes in the food menu items. Only two menu items $(7.2 \%)$ remained on the menu without any changes. All the other menu items $(92.8 \%)$ were modified or removed from the menu. The prices of more than half of the food items ( 17 items) were changed while nine items $(32.1 \%)$ were completely eliminated. In short, the food menu underwent extensive revisions.

Table 3. Revisions to the Beverage Menu

\begin{tabular}{llcc}
\hline $\begin{array}{l}\text { Menu } \\
\text { Revisions }\end{array}$ & Menu Items & $\begin{array}{c}\text { Frequency } \\
\text { (n) }\end{array}$ & $\begin{array}{c}\text { Percent } \\
\text { \% }\end{array}$ \\
\hline Promotion & - & - & 0.0 \\
\hline Repositioning & - & - & 0.0 \\
\hline Retention & $\begin{array}{l}\text { B4, B7, B19, B21, B22, B23, B24, B25, B26, } \\
\text { B27, B28, B29 }\end{array}$ & 12 & 41.4 \\
\hline $\begin{array}{l}\text { Make changes } \\
\text { (Price Change) }\end{array}$ & B1, B2, B3, B5, B6, B8, B9, B10, B11, B12, & 17 & 58.6 \\
\hline Elimination & - & & \\
\hline Total & & - & 0.0 \\
\hline
\end{tabular}

There were fewer changes in the beverage menu than the food menu. Table 3 shows that retention and price change were applied but not promotion, positioning, and removal. There was only one revision. That is, 12 menu items (41.4\%) remained unchanged while 17 menu items (58.6\%) were repriced.

Picture 2 shows the new menu cards after the rescheduling, pricing, and design. It shows more fundamental changes to the food menu than the beverage menu. The nine removed products include carrot-cinnamon, cherry almond cakes (cake category), granola (the diet products category), kivrım dessert, homemade baklava (desserts in the syrup category), magnolia pudding, chocolate crumble (puddings category), and spinach pastry, crepe Suzette (pastries category). The two products offered in the tea-time category were retained unchanged. 


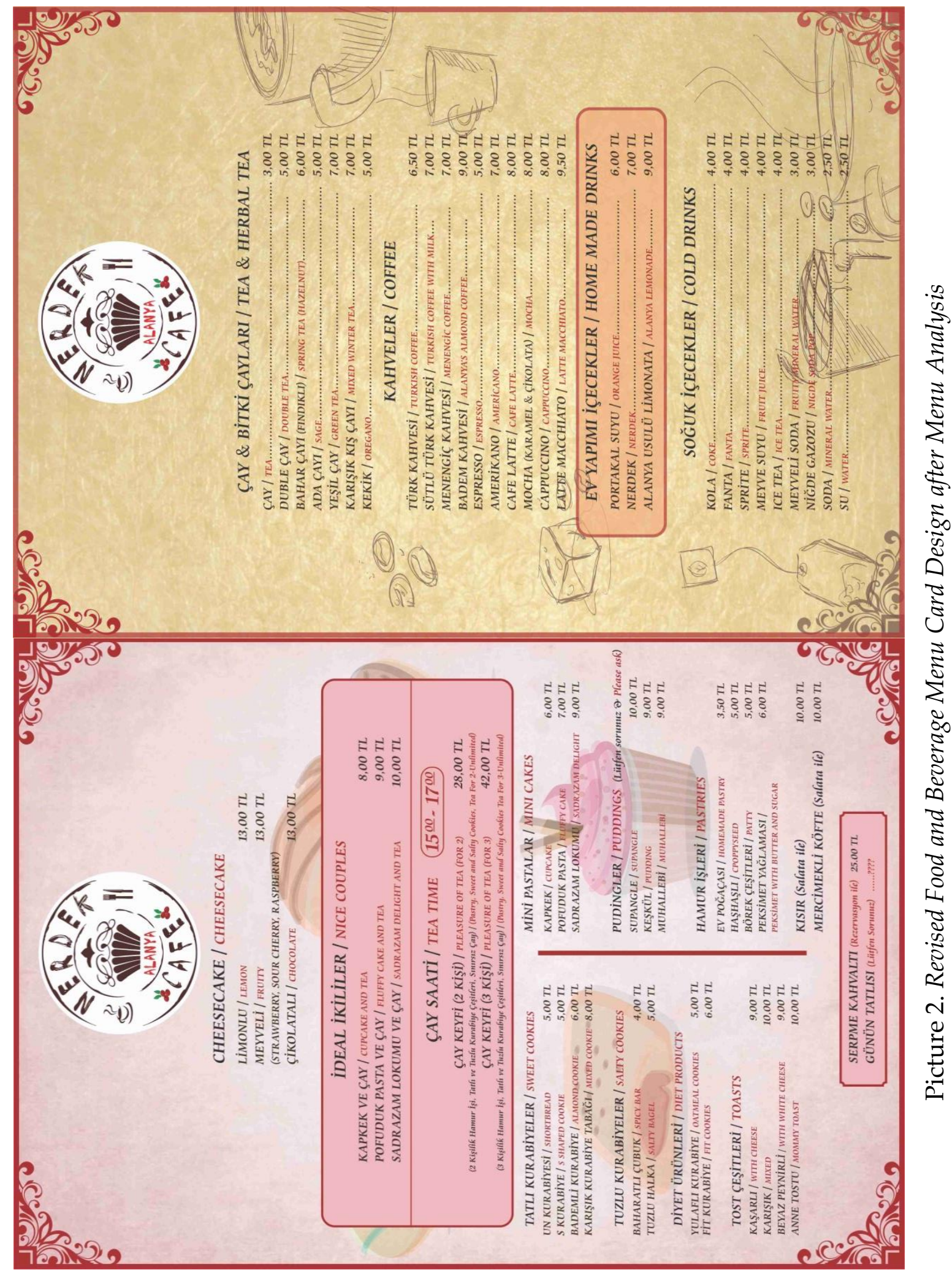




\section{Reasons for Revisions}

The final phase of the study focuses on the third research question: What caused the menu revisions after the menu analysis?" Table 4 provides brief explanations of these revisions. The retention of food and beverages on the menu card as originally planned is explained by the exact meeting of the business objectives and customer expectations of these food and beverages. Apart from retention, there were seven revision reasons under the 3 themes: change, elimination and adding new products.

Table 4. Reasons for Revisions after Menu Analysis

\begin{tabular}{|c|c|c|}
\hline $\begin{array}{l}\text { Revision } \\
\text { Type }\end{array}$ & $\begin{array}{l}\text { Reasons for } \\
\text { Revision }\end{array}$ & Sample Quotes \\
\hline Retention & $\begin{array}{l}\text { Meeting business } \\
\text { objectives and } \\
\text { Matching customer } \\
\text { expectations }\end{array}$ & $\begin{array}{l}\text { "All the foods and beverages remaining in the } \\
\text { menu, which we do not change, meet the business } \\
\text { purposes and consumer expectations." P3 }\end{array}$ \\
\hline & $\begin{array}{l}\text { Increase in } \\
\text { material costs }\end{array}$ & $\begin{array}{l}\text { "We made some changes in the prices depending } \\
\text { on the market conditions. For example, since } \\
\text { Turkish coffee is indexed to the dollar, we had to } \\
\text { raise the price." P1 }\end{array}$ \\
\hline Change & $\begin{array}{l}\text { Willingness to } \\
\text { generate more } \\
\text { profits due to } \\
\text { increased demand } \\
\text { flexibility }\end{array}$ & $\begin{array}{l}\text { "One of the drinks we sell the most is tea ... The } \\
\text { price of tea we set as } 3.00 \text { liras. Since our } \\
\text { customers knew our service quality, they did not } \\
\text { react to this increase." P2 } \\
\text { "Since it is a product we like and is demanded by } \\
\text { customers, we reduced the cheesecake prices and } \\
\text { the portion size to prevent waste and increase } \\
\text { demand." P2 }\end{array}$ \\
\hline \multirow{4}{*}{ Elimination } & $\begin{array}{l}\text { Increase in } \\
\text { material costs }\end{array}$ & $\begin{array}{l}\text { "The cost of cherry almond cake is quite high ... } \\
\text { We saw that it wasn't selling." P3 }\end{array}$ \\
\hline & $\begin{array}{l}\text { Troublesome } \\
\text { products }\end{array}$ & $\begin{array}{l}\text { "There was granola in the diet products category. } \\
\text { We took it out because it was difficult to prepare." } \\
\text { P3 }\end{array}$ \\
\hline & $\begin{array}{l}\text { Reduced customer } \\
\text { demand }\end{array}$ & $\begin{array}{l}\text { "We removed the desserts in syrup from the } \\
\text { menu. Our guests did not prefer it." P1 }\end{array}$ \\
\hline & $\begin{array}{l}\text { Short shelf life of } \\
\text { menu item }\end{array}$ & $\begin{array}{l}\text { "Homemade baklava spoils in two or three days. } \\
\text { This is the biggest problem." P2 }\end{array}$ \\
\hline \multirow{2}{*}{$\begin{array}{l}\text { Adding New } \\
\text { Products }\end{array}$} & $\begin{array}{l}\text { Meeting customer } \\
\text { requests and } \\
\text { expectations }\end{array}$ & $\begin{array}{l}\text { "There was very serious demand for breakfast. I } \\
\text { mean, we had many customers who said I want } \\
\text { to come here and have breakfast." P2 }\end{array}$ \\
\hline & $\begin{array}{l}\text { Request for } \\
\text { balance in the } \\
\text { menu }\end{array}$ & $\begin{array}{l}\text { "Our menu consisted mostly of desserts. We wanted to } \\
\text { balance this with savory foods. For this, we added } \\
\text { products such as toast and salad to the menu." P1 }\end{array}$ \\
\hline
\end{tabular}


The first reason for menu changes was increased product costs, which directly raises product prices. In addition, some products were repriced to increase profits and respond to demand flexibility. That is, raising the prices of products that are in high demand and have high-profit margins will contribute more to the business. Conversely, the prices of some products were reduced, such as cheesecakes. Reducing both the portion sizes and the price simultaneously prevented waste and increased customer demand.

The first two reasons for removing products from the menu were high costs or laborious preparation, as with cherry almond cakes and granola. The third reason was lack of demand. Fourth, some of the outsourced products rapidly spoiled particularly the homemade baklava as a crunchy and syrupy dessert. Due to the lack of demand for these products, it was decided to remove them from the menu.

New products were added to the menu for two reasons. First, customers wanted more savory items. Secondly, the operators wanted only freshly made products. Based on the menu analysis phase, several products were added in accordance with customer requests, such as toast, salads and breakfast. This improved the balance between the number of sweet and savory items.

After the first year, the company completely stopped buying outsourced ready-made products, such as spinach pastry and kivrim desserts. Instead, the operators decided to prepare all products in house. Finally, the menu continued to offer both local and international delicacies in accordance with the criteria set during the planning phase.

\section{DISCUSSION AND CONCLUSIONS}

This study focused on understanding how the menu management process model is applied in practice. Each step of the process was followed and explained using observations, document analysis and interviews with the three participants. The findings suggest both theoretical and practical inferences about the model.

\section{Theoretical Implications}

During the planning stage, the food and beverage business operators decide which products to offer. One of the most significant factors is the business 
concept because the process is deeply affecting by whether the business is a five-star hotel restaurant (Seyitoğlu, 2017), a chain restaurant (Jones \& Mifli, 2001; Glanz et al., 2007), or a fine dining restaurant. For example, in a Michelin-starred restaurant business, menu planning is often shaped by the chefs' intuitions and professional experience (Ottenbacher \& Harrington, 2007) whereas the more centralized authority in a chain restaurant business considers more rational factors, such as profitability and efficiency (Ottenbacher \& Harrington, 2009). This understanding of rationality also applies when consumers are at the center (Kivela, 2003) or nutrition principles (Johnson et al., 2002) are taken into account. In short, the approaches adopted in the business concept and planning determine the product choices. For a Michelin star restaurant, product quality is one of the main factors in product selection (Ottenbacher \& Harrington, 2007), whereas low cost and efficiency may be more important in low-cost restaurant chains (Ottenbacher \& Harrington, 2009). Other factors include competitors (Antun \& Gustafson, 2005), qualities of products (Aktaş Alan \& Suna, 2019), profitability (Kwong, 2005), and diversity (Morrison, 1996; Bernstein et al., 2008).

Since the food and beverage business studied here was a small boutique cafe, they adopted a classical menu planning approach, which is more flexible in the planning stage and generally based on the operators' intuition. By the end of the process, the business reached a point where guests' requests were considered, so they preferred an approach they defined as balancing the menu. In addition, they demonstrated a rational understanding by determining in detail how to procure the products. During the pricing stage it is essential to develop an effective pricing strategy for marketing the products. Restaurant businesses can and do adopt two different kinds of pricing strategies at this point (Raab et al., 2009): objective and subjective. In objective pricing, operators prefer costbased pricing, that Raab et al. (2009) also find in restaurant businesses. In this method, the costs of the products are determined, and pricing is made by placing a particular profit margin on these costs. In subjective pricing, both reasonable pricing and reference pricing methods are used (Rizaoğlu $\&$ Hançer, 2005). That is, operators calculate a fair price that consumers can pay or consider the pricing by competing businesses. Raab et al. (2009) and Yim et al. (2014) report similar findings to this study in that both competitors' prices and consumers' perceptions of value influence pricing. However, the loss leader pricing strategy (Cohen et al., 2007) was not used.

Apart from determining the sales price, some studies indicate that food and beverages can be sold more efficiently by developing specific 
pricing strategies. More specifically, the exact numbers used for the decimals can mean various meanings, such as cheapness or quality. Thus, '.00' emphasizes quality whereas '.99' emphasizes low price or a promotion (Parsa \& Naipaul, 2008). In the case studied here, except for one menu item (Turkish Tea: 2.50£), only zeros were used. This can be explained by the fact that the restaurant also wanted to demonstrate, through pricing, its desire to offer high quality, homemade, natural products. Hançer et al. (2007) also reported that ' .00 ' emphasizes quality. If the design phase is not done properly then even a well-planned menu can still fail (Choi et al., 2010). The vast majority of research on menu design aims to understand consumer reactions to menu card design.

Physically, the café's menu was designed as a single piece with separate cards to make foods and beverages distinct. To make the categories more understandable, the menu used different colors and font sizes for item explanations and languages. The menu's pink background color reflected the business concept rather than increasing sales, as discussed by Baiomy et al. (2019), Magnini and Kim (2016), and Kim and Lee (2020).

Although research suggests that images on menu cards increase sales (Hou et al., 2017), the café's menu cards avoided pictures in accordance with the preferences of the operators. In terms of naming menu items, some items were named in relation to place names or preparation stages to attract attention. For example, 'Alanya-style lemonade' emphasizes that the product is unique to a region while 'Homemade baklava' indicates naturalness. The use of such terminology helps the business deliver the messages it wants to convey to customers through the menu. This reflects the advice by Bowen and Morris (1995) on menu design: "Carefully chosen words in a conversation can make this conversation exciting and memorable; the same applies to menus. (p. 4)" Another highlight in the design was explanations of the menu items. Filimonau and Krivcova (2017) suggest five different topics for explanations: source, nutrients, calories, allergens, and production methods. In this study, there was a new description of food on the menu cards, specifically the contents of the socalled 'nice couples', in which food and beverages are presented together. In addition, the café's menu stated that breakfast needs to be booked and that the dessert of the day varies. Recently, several studies (Dipietro et al., 2006; Hwang \& Lorenzen, 2008) have discussed the importance of health information in menu descriptions. However, there were no such explanations on the café's menu cards. Research also suggests that symbols next to menu items can increase sales. For example, Guéguen et al. (2012) 
showed that water drop marks placed next to seafood items increases sales. However, the café operators did not use this strategy.

Menu design also focuses on the position of items on the menu card. The parts that consumers most focus on are called sweet spots, based on the assumption that people best remember the first and last things they read or hear (Bowen \& Morris, 1995). The sweet spots of menu cards are the upper parts (Bowen \& Morris, 1995) or middle parts (Choi et al., 2010). However, the café's operators paid little attention to this in positioning items on the menu card. Instead, the participants explained that they placed the products they wanted to sell most at the top, which is similar to the findings of Özdemir and Nebioğlu (2018), who examined 86 restaurant menus, and concluded that the strategic locations of the items were not consciously selected. They suggested that this was because the graphic layout of the menu was more prominent than strategic positioning.

According to Özdemir and Çalışkan (2014), the operation phase is largely neglected in the literature. The prominent issues are production and service processes, food safety practices, sales forecasts, budgeting and cost control. Rather than the above topics, marketing was more emphasized in the current case study, particularly promotional activities and customer relations. This can be considered natural for a newly opened food and beverage company.

In the analysis phase, the menu performance can be evaluated conceptually or practically in many different ways (Jones \& Mifli, 2001). As Özdemir (2012) mentioned, there are four main approaches to measuring menu performance: matrix-based, improved matrix-based, profitability analyses, and multivariate analyses. Two basic menu analysis methods are used in the Menu Management Process Model: plate waste analysis, and sales and profitability, which is similar to the menu engineering approach of Kasavana and Smith (1982). The café operators did not evaluate menu items in terms of profitability and popularity. Instead, they examined plate waste and solicited feedback from customers, and then tried to make judgements by focusing on sales figures. These findings are similar to Kwong (2005), who found that Asian restaurant operators perform menu analysis based on past experience and intuition. Özdemir \& Nebioğlu (2015) also reported that five-star hotel chefs used similar strategies. In short, intuitive approaches to menu analysis remain prominent.

There are four main categories of reasons for changing menus: financial issues (increase in material costs, desire to make more profit), consumer issues (lack of demand), product issues (laborious products, 
products with short shelf life), and menu balance issues. Bernstein et al. (2008) suggested several different reasons for menu changes, such as seasonality, market availability, and promotional activities. In the present study, the two main reasons were customer demand and product features. Thus, although only promotional activities may be partly related to demand, it differs from the findings of Bernstein et al. (2008), which emphasized the availability of the product in general. Instead, the findings in this study are similar to those of Glanz et al. (2007), regarding the removal of menu items that increase kitchen workload and Aktaş Alan and Suna (2019) regarding the impact of customer demands. The café's menu was revised in ways specified by Taylor and Brown, (2007), mostly because of these two reasons. Some products remained the same, others were given new prices or portion sizes, and some new menu items were added. The type of revision is also significant. In relation to the strategies proposed by Jones and Mifli (2001), the café operators adopted minimal regulation and menu item development strategies.

Another issue concerning menu revision is the amount of change. The café operators changed or removed $92.8 \%$ of the menu items, which indicates a drastic revision. This can be explained in relation to the business concept. As a boutique café with only one branch, it was easier than planning, removing and adding new products in a chain restaurant with many branches. That would be a long and challenging process because the menus are determined by a central administration. As Ottenbacher and Harrington (2009), point out, changes to menus and innovation become more challenging and complex as the business grows and expands, and the number of branches increases.

\section{Practical Implications}

The study has several practical implications as well. Menu planning requires the synthesis of different factors, such as the desire to balance the menu, personnel qualifications, customer demands and product specifications. In this regard, practitioners should design products suitable for customer demands and business purposes and diversify the menu to suit the demands of a wide customer base. Pricing is made using both objective and subjective pricing methods while considering the possible customer reactions. While pricing, objective methods should be supported by subjective methods while considering consumer price sensitivities and perceptions. Although design is an important issue, design recommendations (strategic location of menu items, menu item 
descriptions, etc.) are not taken into account in the literature. Instead, attention is paid to graphic design. Operators should therefore be informed about menu design issues, such as the physical properties of the menu card, the menu layout, and labeling menu items.

In operation, the highlights are promotional marketing, in-service training, and customer relationship management. Promotion efforts in a newly established business, staff training, and customer relations are natural developments. Menu implementation may be the most complex area to focus on. At this stage, operators and employees should consider customer feedback and improve the menu by finding quick solutions. Heuristic methods predominate in the analysis stage, which depends on the business concept. In a small business, it is more feasible to analyze intuitively. However, as the business grows, menu analysis may need to be done more professionally using formal methods. The menu management process is one of the most fundamental issues in restaurant management, requiring the operators' full attention. Each stage requires the use of different qualifications and skills and those responsible for menu management should consider different variables for each stage. The findings from the case study show that both rational and intuitive thinking is involved in menu management. Used in combination, these two strategies can help the business to understand the difference between planned and realized targets.

\section{Limitations and Future Research}

The findings in this study confirm that the menu management process is a cyclical model of five consecutive stages, as suggested by Çalışkan and Özdemir (2011). However, since food and beverage businesses can be designed in different sizes and according to different concepts, the strategies used in each stage may differ. This study was conducted on a boutique café. Therefore, future research should investigate different types of food and beverage businesses, such as fast-food chains, hotel restaurants, and fine dining restaurants. This will provide a more accurate idea of what is similar or different in the earlier stages of the model. 


\section{ACKNOWLEDGMENT}

I thank the participants in the study and Prof. Dr. Bahattin Özdemir for their valuable contributions to the manuscript.

\section{REFERENCES}

Aktaş Alan, A., \& Suna, B. (2019). Gastronomi şehri “Gaziantep'te" menü planlama uygulamalarına güncel bakış. [A contemporary outlook on menu planning applications in the city of gastronomy "Gaziantep"]. Journal of Tourism and Gastronomy Studies, 7(2), 1328-1343. Retrieved from https://www.jotags.org/2019/vol7_issue2_article38.pdf

Antun, J. M., \& Gustafson, C. M. (2005). Menu analysis. Journal of Nutrition in Recipe \& Menu Development, 3(3-4), 37-41. https://doi.org/10.1300/J071v03n03

Baiomy, A. E., Jones, E., \& Goode, M. M. H. (2019). The influence of menu design, menu item descriptions and menu variety on customer satisfaction. A case study of Egypt. Tourism and Hospitality Research, 19(2), 213-224. https://doi.org/10.1177/1467358417708228

Başkale, H. (2016). Nitel araştırmalarda geçerlik, güvenirlik ve örneklem büyüklügü̈nün belirlenmesi. [Determination of Validity, Reliability and Sample Size in Qualitative Studies]. Dokuz Eylül Üniversitesi Hemşirelik Fakültesi Elektronik Dergisi, 9(1), 23-28.

Baxter, P., \& Jack, S. (2008). Qualitative case study methodology: study design and implementation for novice researchers. The Qualitative Report Volume, 13(4), 544559. https://doi.org/10.2174/1874434600802010058

Bernstein, D., Ottenfeld, M., \& Witte, C. L. (2008). A study of consumer attitudes regarding variability of menu offerings in the context of an upscale seafood restaurant. Journal of Foodservice Business Research, 11(4), 398-411. https://doi.org/10.1080/15378020802519769

Bowen, J. T., \& Morris, A. J. (1995). Menu design: Can menus sell? International Journal of Contemporary Hospitality Management, $4(4)$, 4-9. https://doi.org/10.1108/09596119510091699

Çalışkan, O., \& Özdemir, B. (2011). Restoran Yönetimi [Restaurant management]. In İ. Pırnar, O. İçöz, O. Çulha (Eds), Uluslararası Turizm İşletmeciliği (pp. 251-282). Ankara: Nobel Yayıncililık.

Cho, M., Bonn, M. A., Han, S. J., \& Kang, S. (2018). Partnership strength and diversity with suppliers. International Journal of Contemporary Hospitality Management, 30(3), 15261544. https://doi.org/10.1108/IJCHM-01-2017-0016

Choi, J., Lee, B., \& Mok, J. (2010). An experiment on psychological gaze motion an experiment on psychological gaze motion: A re-examination of item selection behavior of restaurant customers. Journal of Global Business and Technology, 6(1), 6880.

Cohen, E., Ghiselli, R., \& Schwartz, Z. (2007). The effect of loss leader pricing on restaurant menus' product portfolio analysis. Journal of Foodservice Business Research, 9(1), 2138. https://doi.org/10.1300/J369v09n01_03

Cohen, E., Mesika, R., \& Schwartz, Z. (1998). A multidimensional approach to menu sales mix analysis. Praxis, 2(1), 130-144. 
Creswell, J. W. (2013). Nitel araştırma yöntemleri, beş yaklaşıma göre nitel araştırma ve araştırma deseni [Qualitative Inquiry and Research Design: Choosing Among Five Approaches] (S. B. Bütün, \& M. Demir, Trans.). Ankara: Siyasal Yayın Dağıtım.

Dipietro, R. B., Roseman, M., \& Ashley, R. (2006). A study of consumers' response to quick service restaurants' healthy menu items. Journal of Foodservice Business Research, 7(4), 59-77. https://doi.org/10.1300/J369v07n04_03

Elo, S., \& Kyngäs, H. (2008). The qualitative content analysis process. Journal of Advanced Nursing, 62(1), 107-115. https://doi.org/10.1111/j.1365-2648.2007.04569.x

Filimonau, V., \& Krivcova, M. (2017). Restaurant menu design and more responsible consumer food choice: An exploratory study of managerial perceptions. Journal of Cleaner Production, 143, 516-527. https://doi.org/10.1016/j.jclepro.2016.12.080

Glanz, K., Resnicow, K., Seymour, J., Hoy, K., Stewart, H., Lyons, M., \& Goldberg, J. (2007). How major restaurant chains plan their menus. The role of profit, demand, and health. American Journal of Preventive Medicine, 32(5), 383-388. https://doi.org/10.1016/j.amepre.2007.01.003

Graneheim, U. H., \& Lundman, B. (2004). Qualitative content analysis in nursing research: Concepts, procedures and measures to achieve trustworthiness. Nurse Education Today, 24(2), 105-112. https://doi.org/10.1016/j.nedt.2003.10.001

Guéguen, N., Jacob, C., \& Ardiccioni, R. (2012). Effect of watermarks as visual cues for guiding consumer choice: An experiment with restaurant menus. International Journal of Hospitality Management, 31(2), 617-619. https://doi.org/10.1016/j.ijhm.2011.04.008

Hançer, M., Biçici, F., \& Tanrısevdi, A. (2007). Fiyat sonu yazım stratejileri: Kafe ve restoran menü fiyatlarının öğrenci algıları üzerindeki etkisini belirlemeye yönelik nitel bir çalışma [Price ending strategies: a qualitative study focusing on the effects of students' perceptionsfor cafe and restaurant menu prices]. Anatolia: Turizm Araştırmaları Dergisi, 18(1), 21-37.

Hou, Y., Yang, W., \& Sun, Y. (2017). Do pictures help? The effects of pictures and food names on menu evaluations. International Journal of Hospitality Management, 60, 94103. https://doi.org/10.1016/j.ijhm.2016.10.008

Hwang, J., \& Lorenzen, C. L. (2008). Effective nutrition labeling of restaurant menu and pricing of healthy menu. Journal of Foodservice, 19(5), 270-276. https://doi.org/10.1111/j.1748-0159.2008.00108.x

İyitoğlu, V., \& Nebioğlu, O. (2017). A case study on the application of periodical menu analysis. The First International Congress on Future of Tourism: Innovation, Entrepreneurship and Sustainability, 1526-1529.

Johnson, L. J., Raab, C., Champaner, E., \& Leontos, C. (2002). Chefs' perception of the importance of nutrition in menu planning. Pakistan Journal of Nutrition, 1, 85-88. https://doi.org/10.3923/pjn.2002.85.88

Jones, P., \& Mifli, M. (2001). Menu development and analysis in UK restaurant chains. Tourism Hospitality Research, 3(1), 61-71. https://doi.org/10.1177/146735840100300105

Kasavana, M. L., \& Smith, D. J. (1982). Menu engineering. Lansing, MI.: Hospitality Publications Inc.

Kelly, T. J., Kiefer, N. M., \& Burdett, K. (1994). A demand-based approach to menu pricing. Cornell Hotel and Restaurant Administration Quarterly, 35(1), 48-52.

Kılıç, S. (2015). Kappa test. Journal of Mood Disorders, 5(3), 142. https://doi.org/10.5455/jmood.20150920115439 
Kim, S., \& Lee, S. (2020). Influences of background colors and calorie information disclosure on consumers' psychological process. Journal of Foodservice Business Research, 23(3), 228-245. https://doi.org/10.1080/15378020.2020.1728026

Kim, S., \& Magnini, V. P. (2016). Prompting restaurant diners to eat healthy: Atmospheric and menu-related factors. Journal of Foodservice Business Research, 19(3), 236-254. https://doi.org/10.1080/15378020.2016.1175897

Kincaid, C. S., \& Corsun, D. L. (2003). Are consultants blowing smoke? An empirical test of the impact of menu layout on item sales. International Journal of Contemporary Hospitality Management, 15(4), 226-231. https://doi.org/10.1108/09596110310475685

Kivela, J. (2003). Results of a qualitative approach to menu planning using control and experimental groups. Journal of Food Service Business Research, 6(4), 43-65. https://doi.org/10.1300/J369v06n04_03

Kwong, L. Y. L. (2005). The application of menu engineering and design in Asian restaurants. International Journal of Hospitality Management, 24(1), 91-106. https://doi.org/10.1016/j.ijhm.2004.05.002

LeBruto, S., Quain, W., \& Ashley, R. (1995). Menu engineering: A model including labor. Hospitality Review, 13(1), 5.

Magnini, V. P., \& Kim, S. (2016). The influences of restaurant menu font style, background color, and physical weight on consumers' perceptions. International Journal of Hospitality Management, 53, 42-48. https://doi.org/10.1016/j.ijhm.2015.11.001

McCall, M., \& Lynn, A. (2008). The effects of restaurant menu item descriptions on perceptions of quality, price, and purchase intention. Journal of Foodservice Business Research, 11(4), 439-445. https://doi.org/10.1080/15378020802519850

Miller, J. (1980). Menu pricing and strategy. Boston: CBI.

Morrison, P. (1996). Menu engineering in upscale restaurants. British Food Journal, 99(10), 388-395. https://doi.org/10.1108/00070709710195194

Ottenbacher, M., \& Harrington, R. J. (2007). The innovation development process of Michelin-starred chefs. International Journal of Contemporary Hospitality Management, 19(6), 444-460. https://doi.org/10.1108/09596110710775110

Ottenbacher, M. C., \& Harrington, R. J. (2009). The product innovation process of quickservice restaurant chains. International Journal of Contemporary Hospitality Management, 21(5), 523-541. https://doi.org/10.1108/09596110910967782

Özdemir, B. (2012). A review on menu performance investigation and some guiding propositions. Journal of Foodservice Business Research, 15(4), 378-397. https://doi.org/10.1080/15378020.2012.734217

Özdemir, B., \& Çalışkan, O. (2014). A review of literature on restaurant menus: Specifying the managerial issues. International Journal of Gastronomy and Food Science, 2(1), 313. https://doi.org/10.1016/j.ijgfs.2013.12.001

Özdemir, B., \& Nebioğlu, O. (2015). Uygulamada Menü Analizi Nasıl Yapılmaktadır? Beş Yıldız Otellerin Mutfak Şeflerinin Görüşleri [How is menu analysis performed in practice? Views of chefs from five star hotels]. Anatolia: Turizm Araştırmaları Dergisi, 26(2), 251-263. 10.17123/atad.vol26iss225595

Özdemir, B., \& Nebioğlu, O. (2018). Use of menu design techniques: Evidences from menu cards of restaurants in Alanya. Advances in Hospitality and Tourism Research (AHTR), 6(2), 205-227. https://doi.org/10.30519/ahtr.440123

Parsa, H. G., \& Naipaul, S. (2008). Price-ending strategies and managerial perspectives: a reciprocal phenomenon - part I. Journal of Services Research, 7(2), 7-27.

Pavesic, D. V. (1983). Cost-margin analysis: A third approach to menu pricing and design. International Journal of Hospitality Management, 2(3), 127-134. 
Raab, C., \& Mayer, K. (2007). Menu engineering and activity-based costing - can they work together in a restaurant? International Journal of Contemporary Hospitality Management, 19(1), 43-52. https://doi.org/10.1108/09596110710724152

Raab, C., Mayer, K., Kim, Y. S., \& Shoemaker, S. (2009). Price-sensitivity measurement: A tool for restaurant menu pricing. Journal of Hospitality and Tourism Research, 33(1), 93-105. https://doi.org/10.1177/1096348008329659

Reynolds, D. (2004). An exploratory investigation of multiunit restaurant productivity assessment using data envelopment analysis. Journal of Travel and Tourism Marketing, 16(2-3), 19-26.

Reynolds, Dennis, Merritt, E. A., \& Pinckney, S. (2005). Understanding menu psychology. International Journal of Hospitality $\mathcal{E}$ Tourism Administration, 6(1), 1-9. DOI:10.1300/J149v06n01_01

Rızaoğlu, B., \& Hançer, M. (2005). Menü ve Yönetim [Menu and management]. Ankara: Detay Yayıncilik.

Seyitoğlu, F. (2017). Components of the menu planning process: the case of five star hotels in Antalya. British Food Journal, 119(7), 1562-1577. https://doi.org/10.1108/BFJ-112016-0560

Sezgin, M., Zerenler, M., \& Karaman, A. (2008). Otel işletmelerinin menü planlamasında yaratıcılık, yenilikçilik, girişimcilik faaliyetleri üzerine bir araştırma. [A research on creativity innovativeness and entrepreneurship activities of menu planning in hotel operations]. Sosyoekonomi, 2, 127-142.

Taylor, J. J., \& Brown, D. M. (2007). Menu analysis: A review of techniques and approaches. Hospitality Review, 25(2), Article 6.

Yim, E. S., Lee, S., \& Kim, W. G. (2014). Determinants of a restaurant average meal price: An application of the hedonic pricing model. International Journal of Hospitality Management, 39, 11-20. https://doi.org/10.1016/j.ijhm.2014.01.010 